\title{
CONSTITUIÇÃO, GOVERNO E DEMOCRACIA NO BRASIL'
}

\section{Cláudio Gonçalves Couto Rogério Bastos Arantes}

To embody a right in an entrenched constitutional document is to adopt a certain attitude towards one's fellow citizens. That attitude is best summed up as a combination of self-assurance and mistrust: self-assurance in the proponent's conviction that what he is putting forward really is a matter of fundamental right and that he has captured it adequately in the particular formulation he is propounding; and mistrust, implicit in his view that any alternative conception that might be concocted by elected legislators next year or in ten years' time is so likely to be wrong-headed or ill motivated that his own formulation is to be elevated immediately beyond the reach of ordinary legislative revision.

Jeremy Waldron, Law and disagreement

* Para a realização desta pesquisa, os autores contaram com o auxílio do CNPq e da PUC-SP.

Artigo recebido em janeiro/2005

Aprovado em fevereiro/2006

\section{Introdução}

Um dos aspectos mais evidentes e controversos da democracia brasileira contemporânea diz respeito ao fato de que a nossa Constituição, promulgada em outubro de 1988, não adquiriu até o momento as condições de estabilidade e permanência que normalmente caracterizam os textos constitucionais.

Observando-se a dinâmica política e a produção legislativa pós-1988, é possível afirmar, sem exagero, que o país permaneceu numa espécie de agenda constituinte, como se, paradoxalmente, o processo de reconstitucionalização não houvesse se encerrado em outubro daquele ano (Couto, 1997, 1998). Por razões que este texto pretende elucidar, o fato é que os governos posteriores a 1988 se viram obrigados a desenvolver boa parte de sua produção normativa ainda no plano constitucional, isto é, por meio de modificações, acréscimos e/ou supressões de dispositi- 
vos localizados na própria Carta. Tomar decisões e implementar políticas governamentais são atividades que, no Brasil pós-1988, não lograram adquirir uma rotina apenas infraconstitucional. Pelo contrário, boa parte dessas atividades teve lugar no nível superior da hierarquia legislativa, ou seja, na própria Constituição.

À parte o fato de nossa história constitucional ser marcada pela instabilidade (estamos na oitava constituição desde a Independência do país, e a durabilidade média das Cartas, desconsiderados os diferentes tipos de regime que as ensejaram, é pouco maior do que duas décadas), o texto de 1988 parecia refletir um novo estágio de maturidade política e de longevidade institucional, coroando e habilitando ao pleno desenvolvimento a democracia recém-conquistada, desta feita, em bases aparentemente mais sólidas do que em períodos anteriores. No entanto, passada a euforia inicial, também a Carta de 1988 cedeu aos velhos signos da instabilidade e da reforma, e aquele que parecia um texto definitivo, capaz de encerrar uma fase da história política do país e dar início a outra com chances de longa durabilidade, foi submetido a freqüentes modificações.

No debate público, as alterações na Constituição de 1988 foram e têm sido defendidas e combatidas ao sabor do jogo político e das forças em disputa. Entre os analistas, entretanto, não se avançou muito além da análise de tipo conjuntural; quando muito, tais alterações foram interpretadas à luz dos processos mais amplos de reforma econômica ou do Estado que marcaram os anos de 1990, mas não logramos desenvolver uma explicação das razões mais específicas das mudanças constitucionais. O objetivo central desse texto é suprir esta lacuna e oferecer um modelo de análise capaz de explicar por que a Constituição de 1988 não adquiriu a estabilidade esperada e o país permaneceu numa espécie de agenda constituinte.

Nosso modelo de análise da Constituição buscará determinar em que medida ela contém dispositivos que podem ser classificados como princípios fundamentais ou dispositivos que mais se assemelham a políticas públicas, e dessa distinção várias conseqüências de ordem política e institucional poderão ser derivadas. O modelo aqui desenvolvido já foi aplicado preliminarmente em estudo anterior (Couto e Arantes, 2003), no qual avaliamos se as emendas constitucionais aprovadas durante os governos de Fernando Henrique Cardoso (1995-1998; 1999-2002) incidiam mais sobre políticas públicas ou sobre princípios propriamente constitucionais. Verificamos naquele trabalho que $68,8 \%$ dos dispositivos integrantes das emendas constitucionais aprovadas durante o período FHC correspondiam a políticas públicas. Diante de tal montante e do fato de que a maior parte das emendas constitucionais fora de iniciativa do Executivo, poderíamos nos questionar: o que levaria um governo a implementar sua agenda de políticas públicas modificando a Constituição, em vez de fazê-lo pela via infraconstitucional?

A pergunta é pertinente, considerando-se que os procedimentos necessários à aprovação de emendas constitucionais são muito mais exigentes do que aqueles requeridos para leis ordinárias ou mesmo para a legislação complementar. Sendo assim, nenhum governo buscaria implementar sua agenda, lançando mão de tal expediente, se não fosse realmente obrigado a fazê-lo. ${ }^{1}$ Uma das possíveis razões para tal escolha poderia ser a exigência, pelos parlamentares, de que determinadas mudanças ocorressem pela via constitucional - talvez como forma de dar guarida a determinadas decisões ao constitucionalizá-las. Outro motivo, a nosso ver mais plausível, é a existência de impedimentos constitucionais à implementação de algumas políticas pelo governo. Ou seja, se a Constituição determina certas políticas públicas, implementar alternativas a elas exigirá - necessariamente - a modificação da Carta. No caso da maior parte das emendas promovidas pelo governo FHC, foi isto de fato o que se verificou.

É necessário, entretanto, além de analisar as emendas, avaliar o próprio texto constitucional originário, com vistas a identificar o peso de cada um dos tipos de dispositivos constitucionais existentes e, considerando-se sua natureza, aferir se foram ou não emendados pelos governos subseqüentes.

A maneira como distinguimos diferentes tipos de dispositivos no interior da Carta deve ser explicada, a fim de que não pareça arbitrária. Para tanto, na seção que se segue, apresentamos os fundamentos teóricos da Metodologia de Análise Constitucional (MAC), por nós desenvolvida. Essa discussão reproduz em parte a seção metodológica de nosso trabalho de 2003, supra- 
mencionado. Contudo, tendo em vista que realizaremos neste texto uma nova aplicação da MAC, julgamos por bem reapresentá-la, incorporando também algumas modificações à versão original, advindas do desenvolvimento da própria pesquisa desde então.

\section{O problema constitucional brasileiro: reformas (não necessariamente) constitucionais}

A hipótese mais usual sobre a permanência de uma agenda constituinte no Brasil pós-1988 (comprovada pela intensa atividade de reforma do texto constitucional nesse período) afirma que a Constituição teria caducado logo após seu nascimento, isto é, o texto teria sofrido de um envelhecimento súbito, como se tivesse mais a ver com o passado do país do que com o presente. Esse descompasso seria especialmente perceptível diante da agenda de reformas estruturais do Estado e do sistema econômico que, gradualmente, foi-se impondo ao país como necessária para a desejada estabilização da economia e a retomada do desenvolvimento em novas bases. Nesse sentido, o fato de a atividade governamental ter continuado a ocorrer no plano constitucional seria conseqüência de uma incompatibilidade substancial entre o conteúdo da Carta de 1988 e os desafios que a nova realidade econômica e política, nacional e internacional, passou a impor ao país.

Desde a promulgação do texto constitucional, vozes dissonantes levantaram-se contra a Carta, acusando-a de constituir, no plano econômico, um obstáculo à modernização do país e, no plano político, um desastre do ponto de vista da governabilidade. Assim, a Constituição escrita sob a égide da "remoção do entulho autoritário" do regime militar pós-64 ter-se-ia tornado ela mesma - e muito rapidamente - uma espécie de "entulho nacional-desenvolvimentista", que precisaria ser removido para permitir a implementação das chamadas reformas orientadas para o mercado.

$\mathrm{Na}$ perspectiva dessa hipótese substantiva, desde José Sarney (1985-1990) e sobretudo com Fernando Collor (1990-1992), questões fundamentais do Estado e do modelo econômico no Brasil começaram a ser levantadas e o novo regi- me constitucional logo foi atacado por seu anacronismo, mal tinha ele nascido. Com Fernando Henrique Cardoso (1995-2002), essa hipótese sobre uma incompatibilidade substancial entre a Carta e os novos desafios estruturais evidenciouse na formação de uma ampla coalizão de governo que, diferentemente do pouco sucesso de seus antecessores, conseguiu implementar um conjunto importante de alterações na Constituição.

Este texto não explora essa hipótese - que investe na incompatibilidade substantiva entre a Carta de 1988 e a agenda de reformas dos anos de 1990 -, pois desejamos mostrar uma outra dimensão do problema constitucional brasileiro. Para além de eventuais anacronismos legados pela Constituição, nosso objetivo é demonstrar que ela nos legou um peculiar modus operandi de produção normativa, com conseqüências significativas para o funcionamento da democracia brasileira. Nesse sentido, nossa hipótese é mais formal do que substantiva, pois se refere ao modo pelo qual o processo decisório e governamental vem-se dando no Brasil. Importa-nos pouco o conteúdo concreto das agendas de governos específicos. Comprovando-se nossa hipótese, a conclusão necessária será que, enquanto vigorar a Carta de 1988 em seus moldes atuais, independentemente do conteúdo de políticas governamentais específicas, levadas à esquerda ou à direita, por progressistas ou conservadores (ou qualquer outra denominação ideológica que se queira dar), a atividade de governo no Brasil seguirá ocorrendo em grande medida no plano constitucional, e estaremos fadados a uma dinâmica constituinte permanente, incapaz de pôr um ponto final no processo iniciado em 1988.

Nosso argumento principal é de que a Carta brasileira de 1988 se caracteriza por ter constitucionalizado formalmente diversos dispositivos que apresentam, na verdade, características de políticas governamentais com fortes implicações para o modus operandi do sistema político brasileiro. Em primeiro lugar, a constitucionalização de políticas públicas faz com que os sucessivos governantes se vejam diante da necessidade de modificar o ordenamento constitucional para poder implementar parte de suas plataformas de governo. Em segundo lugar, construir amplas maiorias legislativas passa a ser condição básica para superar o engessamento prévio a que foi submetida a agenda governa- 
mental pelo constituinte, algo especialmente difícil no contexto institucional de um Estado federativo e de um regime presidencialista multipartidário e bicameral como o brasileiro (Tsebelis, 1997). Por fim, mas não menos importante, esse tipo especial de Constituição tende a causar impacto significativo sobre o funcionamento do sistema de justiça, na medida em que o Judiciário, e especialmente seu órgão de cúpula - o Supremo Tribunal Federal (STF) -, passa a ser mais acionado para controlar a constitucionalidade das leis e demais atos normativos (Arantes, 1997; Arantes e Kerche, 1999), nem sempre relativos a princípios constitucionais fundamentais, mas freqüentemente relativos a políticas públicas.

Quais seriam as razões da grande presença de políticas públicas no interior do texto constitucional? Acreditamos que uma das principais foi o formato que presidiu os trabalhos da Assembléia Nacional Constituinte, favorecendo enormemente a introdução no texto de dispositivos de cunho particularista. Um bom resumo desse processo é dado por Souza e Lamounier:

De acordo com as diretrizes legais estabelecidas pela chamada "Emenda Sarney", os deputados e senadores a serem eleitos em novembro de 1986 reunir-se-iam unicameralmente, decidindo por maioria simples, como uma verdadeira Assembléia Constituinte. Quando esse novo Congresso iniciou os seus trabalhos, no princípio de 1987, houve tensos debates entre os constituintes a respeito dos poderes de que se achavam investidos e sobre a organização a ser adotada nos trabalhos. Predominou, no final, uma organização fortemente descentralizada: subcomissões e comissões temáticas fariam os estudos iniciais, ouvindo a sociedade e votando relatórios preliminares; encerrada essa fase, uma Comissão de Sistematização de 97 membros (cuja presidência coube também ao Senador Afonso Arinos), encarregar-se-ia de preparar o projeto final a ser votado pelo plenário. $\mathrm{O}$ projeto constitucional foi finalmente levado a uma primeira votação em plenário no princípio de 1988. Uma vez que não se formou nenhum bloco monolítico no Congresso, o voto majoritário, na maior parte dos artigos, teve que ser negociado e renegociado vezes sem conta. A segunda e última rodada ocorreu em setembro de 1988, sendo a nova Constituição promulgada a 5 de outubro (Lamounier, 1990, p. 82). ${ }^{2}$
Este processo descentralizado, o quorum de maioria simples e a ausência de um projeto-base do qual se pudesse partir ${ }^{3}$ constituíram fatores favoráveis à introdução no texto dos mais variados dispositivos, bastando para isso que estes contassem com o apoio substancial de algum grupo de pressão ou bancada parlamentar e não ferissem os interesses da maioria congressual. ${ }^{4}$ Nesse sentido, pode-se dizer que as negociações travadas em torno da elaboração da nova Carta ocorreram sob a égide de um amplo log rolling: ao apoio de um grupo $X$ a medidas patrocinadas pelo grupo $Y$, retribuir-se-ia noutra ocasião com o apoio do grupo $Y$ a uma medida de interesse do grupo $X$.

Coelho e Oliveira chamaram a atenção para a dinâmica extremamente descentralizada que marcou os trabalhos constituintes, destacando a falta de paralelo de processos semelhantes na história constitucional brasileira e mesmo no direito comparado. Segundo esses autores,

[...] a construção do futuro Projeto deu-se de fora para dentro, de partes para o todo. Vinte e quatro subcomissões temáticas recolheram sugestões, realizaram audiências públicas e formularam estudos parciais. Estes foram reunidos em blocos de três a três, através de oito comissões temáticas. Só então a Comissão de Sistematização organizou o primeiro anteprojeto, em 15 de julho de 1987. A partir daí, ocorreu uma tramitação formal, com emendas, pareceres e votações. Muitos impasses, negociações, confrontos. Ao todo foram apresentadas, durante as várias fases de comissões, sistematização, primeiro e segundo turnos de plenário, um total de 65.809 emendas. Existiram nove projetos, desde o de 15 de julho de 1987 até a redação final, em setembro de 1988 (Coelho e Oliveira, 1989, p. 20, grifo nosso).

Embora uma análise mais detalhada dos resultados desse método de funcionamento da Constituinte seja recomendável, antes de conclusões generalizantes, parece-nos defensável a hipótese de que esse formato foi o grande responsável pela introdução no texto constitucional de uma grande quantidade de dispositivos mais adequadamente definidos como políticas públicas do que como princípios constitucionais gerais e fundamentais. Nesse sentido, para além dos conteú- 
dos específicos consagrados pela Carta, esse tipo de normatização constitucional engessou formalmente a agenda governamental futura e era mesmo de se esperar, como de fato ocorreu, que boa parte desses dispositivos se tornasse futuramente alvo de tentativas de reforma por parte de novas maiorias parlamentares ou de novas gestões à frente do Executivo. Assim, o baixo grau de universalismo atingido pela Constituição e a grande quantidade de dispositivos particularistas e controversos presentes no texto são fatores que ajudam a entender por que a promulgação da nova Carta ocorreu sob o signo de certa indefinição ou provisoriedade, tendo a própria Constituinte programado uma Revisão Constitucional geral para daí a cinco anos (sob a influência da Constituição portuguesa, que possuía a previsão de revisões a cada cinco anos), por meio do artigo $3^{\circ}$ do Ato das Disposições Constitucionais Transitórias:

Art. $3 .^{\circ}$ A revisão constitucional será realizada após cinco anos, contados da promulgação da Constituição, pelo voto da maioria absoluta dos membros do Congresso Nacional, em sessão unicameral.

Anos mais tarde, por mais que alguns intérpretes da Constituição tenham tentado vincular o artigo $3^{\circ}$ do ADCT aos resultados do plebiscito sobre sistema de governo realizado em 1993, prevaleceu a opinião de que a revisão autoprogramada da Carta deveria ser irrestrita, podendo versar sobre todo o texto.

A Constituição, que nasceu sob o signo da reforma em moto-contínuo, passou, entretanto, pela Revisão Constitucional de 1993/1994 sem que muitas e prometidas alterações fossem feitas no texto original. ${ }^{5}$ Segundo Melo, em um dos estudos mais completos sobre as principais reformas constitucionais no Brasil, o malogro da revisão de 1993/1994 deu-se em virtude de uma conjunção de fatores, a despeito do potencial e das expectativas de mudança que antecederam o processo. Comparativamente aos aspectos que favoreciam a mudança constitucional,

[...] outras características, no entanto, tais como o monopólio, pelo Legislativo, da iniciativa proposi- tiva, a inexistência de policy advocates para as emendas e a simultaneidade de votações reduziam o potencial de mudança por parte do governo. A análise sugere que esse potencial, que o arranjo institucional propiciava, foi anulado pelo impacto devastador de fatores contextuais, tais como os constrangimentos eleitorais, a polarização da agenda pública e a estrutura de incentivos com que se deparavam o Executivo e o Legislativo na conjuntura da CPI do orçamento. O calendário eleitoral, como variável isolada, se constituiu no fator decisivo (Melo, 2002, p. 76).

A análise de Melo é em si reveladora de um aspecto fundamental disso que estamos chamando de o problema constitucional brasileiro. Afinal de contas, por que o sucesso ou o fracasso de um processo de revisão constitucional deveria estar condicionado pelos interesses do "governo", pela presença ou ausência de policy advocates, pelo efeito negativo ("devastador") de fatores "contextuais", pela "conjuntura" política e pelo "calendário eleitoral", se não pelo fato de que essa Constituição é ela mesma uma Carta que encerra muitos dispositivos tipicamente governamentais? Isto é, os fatores identificados por Melo para explicar o fracasso da revisão constitucional de 1993/1994 são a própria confirmação do nosso argumento de que a Constituição criou um modus operandi de produção normativa que vincula os interesses conjunturais, de governo e dos policy advocates, ao marco constitucional. É por essa razão que nossa agenda política seguiu sendo uma agenda constituinte no pós-1988. ${ }^{6}$

O outro exemplo que confirma o argumento sobre a peculiaridade do nosso ordenamento constitucional é justamente o processo de reformas constitucionais conduzido durante os dois mandatos de Fernando Henrique Cardoso na presidência da República. O maior sucesso do governo FHC na implementação de mudanças constitucionais explica-se pela conjunção complexa, porém favorável, de fatores como os mencionados acima por Melo, em grau suficiente para que a agenda governamental de um presidente em particular pudesse vencer os obstáculos da constitucionalização a que ela foi previamente submetida pelo modelo de $1988 .^{7}$

Ao longo de dezoito anos de vigência da Constituição de 1988 transcorridos até 2006, um 
total de 58 emendas constitucionais foram aprovadas, sendo seis durante o referido processo de revisão - as Emendas Constitucionais de Revisão e outras 52 como Emendas Constitucionais comuns. Destas últimas, 35 foram aprovadas durante o governo Fernando Henrique Cardoso (entre os anos de 1995 e 2002) e treze durante o governo Lula. Foram elas, na sua maior parte, propostas de iniciativa do Poder Executivo, recaindo predominantemente sobre matérias que compunham uma agenda tipicamente governamental e não necessariamente constitucional, no sentido mais rigoroso que essa expressão possa conter.

Como distinguir, afinal, princípios fundamentais de dispositivos veiculadores de políticas públicas no âmbito de um texto constitucional? A próxima seção destina-se a formular um modelo que seja capaz disso.

\section{Polity, politics, policy}

Que papéis têm, nas democracias constitucionais, (a) as estruturas do regime, compreendendo os direitos individuais e as regras do jogo político, (b) a competição política e (c) as decisões concretas de governo? Embora cada uma dessas dimensões seja parte constitutiva do processo poliárquico, elas não têm o mesmo significado nem contribuem da mesma forma para o funcionamento do regime democrático. Se quisermos, portanto, compreender corretamente a dinâmica política real das democracias constitucionais, é indispensável verificar como regimes desse tipo são capazes de distinguir e articular essas três dimensões do arcabouço institucional e da dinâmica política.

Em primeiro lugar, é importante considerar que regimes democráticos normalmente se distinguem dos não democráticos pela presença de alguns elementos-chave, a saber:

1. O jogo político ocorre de acordo com regras preestabelecidas.

2. As eleições são periódicas e se sucedem por meio de sufrágio universal.

3. Os mandatos dos eleitos são limitados, tanto temporalmente como no que concerne ao alcance de suas decisões e ações.
4. A vontade majoritária da população e as decisões de seus representantes eleitos prevalecem nos limites das regras preestabelecidas.

5. A oposição é participante legítima do jogo e não deve encontrar impedimentos para chegar ao poder pelo voto popular.

6. Os governantes são responsáveis perante o eleitorado, prestando-lhe contas.

7. Os direitos civis clássicos são garantidos, viabilizando o desenrolar da competição políti$\mathrm{ca}$ - direitos fundamentais operacionais.

8. São assegurados direitos sem os quais os atores políticos não se disporiam a participar da competição democrática - direitos fundamentais condicionantes. ${ }^{8}$

Esses oito elementos estabelecem as regras básicas do jogo político democrático, conformando o que há de essencial na estrutura constitucional de uma poliarquia (Dahl, 1997). Por delinear os contornos fundamentais do regime, definem as condições paramétricas estáveis do jogo político, não se confundido com este ou com seus resultados. Temos aí a primeira dimensão da política democrática, estrutural, a polity. Justamente por definir os parâmetros da convivência poliárquica, a estrutura constitucional se alicerça sobre um indispensável consenso mínimo dos diversos atores políticos quanto a seus aspectos centrais.

Dado se tratar de um acordo institucional básico - um pacto implícito ou explícito entre os atores poliárquicos - os dispositivos por ele estabelecidos têm caráter não controverso, isto é, não dizem respeito àquilo que a competição democrática tem como finalidades: (a) definir a ocupação dos postos de poder por um determinado período e (b) definir quais políticas públicas serão implementadas num dado momento. Estes dois objetivos correspondem, portanto, a duas outras dimensões, mais visíveis e perceptíveis no dia-adia das democracias do que a primeira:

1. A competição política por cargos e influência.

2. A decisão sobre políticas governamentais.

A competição política constitui o próprio jogo e nela estão implícitos os enfrentamentos, as disputas, as negociações, os acordos e as coali- 
zões. Trata-se da dimensão dinâmica da realidade política, ao passo que as condições paramétricas estáveis constituem a sua dimensão estática. Noutras palavras, o jogo político diz respeito à ação (e à interação), ao passo que as condições paramétricas dizem respeito à estrutura, no âmbito da qual ocorrem as ações (e interações). É também no âmbito dessa competição que se definem, nos limites das regras estabelecidas, os que ganham e os que perdem, os que ocuparão os cargos públicos (eletivos ou não) e os que ficarão excluídos do poder, os aliados e os adversários etc. A esta segunda dimensão da realidade política denominamos politics.

Entretanto, além do jogo político há também a importante esfera das decisões de governo, que constitui a terceira dimensão do regime poliárquico. Tais decisões são elas próprias um objetivo e uma decorrência - ao mesmo tempo - do jogo político. Afinal, por que motivos competem os jogadores nas poliarquias? Como certa vez definiu Schumpeter (1980), para ocupar postos de poder e influência; mas também para definir políticas públicas. Sobre estas últimas, ao contrário das condições paramétricas estáveis, espera-se que sejam objetos de controvérsia, e não de consensos mínimos; por isso mesmo, decorrem das disputas políticas conjunturais. Enquanto a primeira dimensão constitui a base para o jogo político, essa última representa seus resultados concretos e circunstanciais. E da mesma maneira como este jogo se desenrola limitado pela estrutura constitucional, o alcance dos resultados também está limitado por essa estrutura - o que não significa dizer que seja predeterminado por ela. ${ }^{?}$ A esta dimensão denominamos policy.

Definimos em inglês as três dimensões da política em decorrência da falta de termos apropriados e claramente diferenciados na língua portuguesa para cada uma delas. Sumarizando, a polity corresponde à estrutura paramétrica estável da política e que, supõe-se, deve ser a mais consensual possível entre os atores; a politics é o próprio jogo político; a policy diz respeito às políticas públicas, ao resultado do jogo disputado de acordo com as regras vigentes. ${ }^{10} \mathrm{O}$ Quadro 1 resume a natureza e as características principais destas três dimensões do processo político democrático.

Como nosso intuito neste artigo é analisar o conteúdo da Constituição brasileira de 1988, não trataremos da dimensão dinâmica do processo democrático, a politics, para concentrarmos nossas atenções na hierarquia normativa que distingue o pacto constitucional (polity) das decisões governamentais (policy). A Figura 1 ilustra esta hierarquia e diversos aspectos a ela relacionados.

A lógica poliárquica supõe que normas constitucionais estruturem o sistema político, estabelecendo condições gerais para seu funcionamento. São por isso genéricas, tanto na definição dos pressupostos formais do jogo, como na esti-

Quadro 1

Natureza das Dimensões Ideais do Processo Político Democrático

\begin{tabular}{|c|c|c|c|c|}
\hline DimENSÃO & NATUREZA & DENOMINAÇÃO & $\begin{array}{l}\text { CARACTERÍSTICA } \\
\text { SUBSTANTIVA }\end{array}$ & $\begin{array}{l}\text { CARACTERÍSTICA } \\
\text { FORMAL }\end{array}$ \\
\hline $\begin{array}{l}\text { NORMATIVIDADE } \\
\text { CONSTITUCIONAL }\end{array}$ & $\begin{array}{l}\text { Parâmetros Gerais } \\
\text { do Jogo Político } \\
\text { (Estrutura) }\end{array}$ & Polity & $\begin{array}{l}\text { Consenso mínimo } \\
\text { pactuado entre } \\
\text { os diversos } \\
\text { atores políticos }\end{array}$ & $\begin{array}{l}\text { Generalidade, } \\
\text { relativa } \\
\text { neutralidade }\end{array}$ \\
\hline $\begin{array}{l}\text { EMbates e } \\
\text { COALIZÕES } \\
\text { POlíticas }\end{array}$ & Jogo Político & Politics & $\begin{array}{l}\text { Relacionamento } \\
\text { dinâmico entre os } \\
\text { atores políticos }\end{array}$ & $\begin{array}{l}\text { Conflito e/ou } \\
\text { Cooperação. }\end{array}$ \\
\hline $\begin{array}{l}\text { NORMATIVIDADE } \\
\text { GOVERNAMENTAL }\end{array}$ & $\begin{array}{l}\text { Resultados } \\
\text { do Jogo Político } \\
\text { (Conjuntura) }\end{array}$ & Policy & $\begin{array}{l}\text { Vitória/Derrota } \\
\text { de diferentes } \\
\text { atores políticos }\end{array}$ & $\begin{array}{l}\text { Especificidade, } \\
\text { controvérsia }\end{array}$ \\
\hline
\end{tabular}


pulação dos limiares e dos limites de seus resultados conjunturais. Nessa dimensão, a constituição corresponde a um pacto entre os atores políticos, refletindo um consenso básico entre eles. Caso não seja assim e a Constituição estipule normas de maior especificidade, que ultrapassem esse consenso básico, ela refletirá a vitória de alguns setores da sociedade sobre outros. Dado seu caráter de maior permanência, tal Constituição consagrará de modo perene interesses circunstanciais, por colocá-los fora do alcance do jogo poliárquico futuro.

A pactuação consensual de princípios constitucionais implica na normatização apenas dos interesses comuns aos diversos setores da sociedade, ou, no máximo, daqueles interesses particulares inegociáveis, sem cuja garantia o convívio pacífico e a competição política leal entre os diversos setores sociais e políticos seriam inviabilizados. Por isso pode-se afirmar que tais princí- pios são relativamente neutros. ${ }^{11} \mathrm{Na}$ medida em que definem somente os parâmetros, os princípios e os limites do jogo político, as normas constitucionais poliárquicas têm caráter genérico, pois medidas específicas para sua efetivação são tomadas conjunturalmente, tendo em vista as circunstâncias particulares com que lidam os governos do dia.

Dada a função estruturante da polity, as normas constitucionais têm caráter soberano, razão pela qual não estão em princípio sujeitas à discussão democrática cotidiana, à qual balizam, resguardando direitos fundamentais e assegurando que a politics transcorra segundo parâmetros previsíveis e estáveis. Normativamente, correspondem a um momento inaugural, no qual se fundaria a polity e se iniciaria o jogo político (Ackerman, 1988). Em virtude disso, são protegidas contra modificações freqüentes, sendo as regras para sua alteração bem mais exigentes do que as necessárias para alterar

Figura 1

Representação Sintética da Hierarquia Decisória

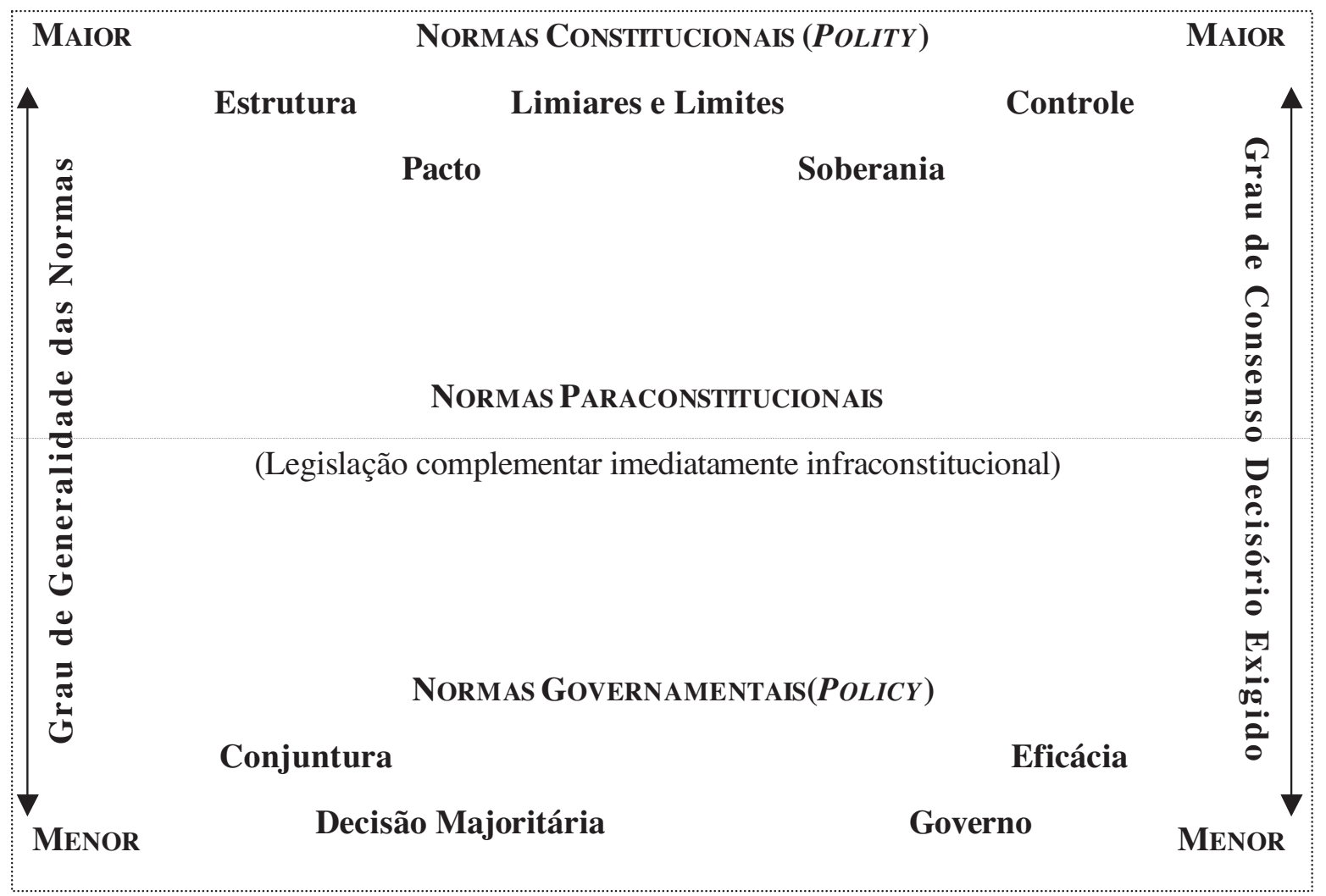


policies: quoruns ampliados de votação, prazos deliberativos dilatados, poder de veto conferido a diversos atores institucionais, consultas populares obrigatórias e, no limite, vedação total a quaisquer mudanças por emendas constitucionais pela legislatura ordinária, requerendo-se nesse caso a realização de uma nova Assembléia Constituinte. ${ }^{12}$ Noutras palavras, o grau de consenso necessário a decisões constitucionais é muito mais amplo do que aquele aplicável às decisões da política "normal", isto é, da política governamental (Idem). Vale observar ainda que nosso modelo tem em vista sistemas políticos dotados de constituições escritas e com algum tipo de controle constitucional das leis e dos atos normativos dos governos, duas características que aumentam o grau de consensualismo do sistema, em detrimento de seu majoritarismo (Lijphart, 1989).

Por outro lado, o governo age na conjuntura; sua ação baliza-se pela eficácia; suas decisões podem - sem maiores problemas - constituir imposições da parte vitoriosa na disputa democrática (a maioria) sobre a parte derrotada (a minoria), assim como podem ser específicas e controversas, no sentido já assinalado. Tudo isto é possível desde que as decisões de governo não contrariem a normatividade constitucional, respeitando os limiares e os limites estipulados. É da natureza do próprio jogo democrático o perde-ganha político; ora um grupo obtém o controle sobre os postos capazes de processar decisões governamentais, ora outro. As oscilações decorrentes desse processo refletem-se diretamente sobre a formulação e a implementação das policies, que são objetos da avaliação do eleitorado o qual - com base num juízo sobre o desempenho do governo - premia ou pune seus representantes nas eleições subseqüentes, por meio de escolhas eleitorais. Se a alternância de grupos (partidos) no governo é uma condição do regime democrático, a variação das políticas públicas (policies) é uma conseqüência prática inevitável (e desejável) desse princípio. A possibilidade de que tal variação de policies ocorra é, portanto, pré-requisito a que a alternância de grupos (partidos) no governo tenha efeitos práticos. Daí as menores exigências das regras decisórias referentes à produção de policies, se comparadas àquelas necessárias para o emendamento constitucional. ${ }^{13}$

\section{Critérios de distinção de matérias constitucionais e não-constitucionais}

Considerando-se as dimensões de polity, politics e policy tal como estabelecidas anteriormente, seria possível distinguir, no interior de uma determinada Constituição escrita, os aspectos fundamentais do ordenamento político relativos à estrutura do regime (polity) daqueles outros que, embora se refiram ao conteúdo material de ações estatais prováveis ou desejáveis (policies), foram abrigados pelo texto constitucional e equiparados formalmente aos princípios da polity.

Nossa intenção, nesta seção, é elaborar critérios objetivos que permitam classificar os dispositivos constitucionais como polity ou policy. A tarefa exige boa dose de argumentação, dado que o texto formal abriga sem distinção dispositivos correspondentes a ambos os princípios, de modo que estabelecer uma hierarquização entre eles é correr um risco considerável.

Como se sabe, o constitucionalismo moderno desenvolveu-se a partir do princípio liberal da limitação do poder político vis-à-vis a liberdade civil e individual. De modo geral, os textos constitucionais modernos preocuparam-se com o estabelecimento dos princípios fundamentais do Estado, ao mesmo tempo em que procuraram definir os limites da ação estatal da maneira mais rigorosa possível. Poder e liberdade são considerados antitéticos na tradição liberal, e essa oposição marcou decisivamente o surgimento das primeiras constituições escritas do final do século XVIII. Contemporaneamente, o conjunto de dispositivos constitucionais relacionados à regulação desse antagonismo vem sendo difundido por meio das noções de Estado de Direito e Rule of Law. Posteriormente, com a ampliação do sufrágio, as Cartas também passaram a ter de lidar com a incorporação de contingentes cada vez maiores da população ao processo político. Dessa forma, às duas noções anteriores acrescentou-se a de Estado democrático.

Uma primeira classificação do texto constitucional, minimalista em termos de polity e policy, deveria retornar às origens do constitucionalismo moderno e aos princípios liberais que marcaram a refundação do Estado, bem como aos princípios democráticos que vieram em seguida, especialmente a ampliação dos direitos de participação. 
Nesse sentido, os seguintes critérios poderiam ser adotados para identificar os dispositivos típicos da polity e, por exclusão, revelar aqueles que poderiam ser considerados veículos de policy. Dentre os princípios de um regime liberal-democrático clássico, formalizados constitucionalmente, apenas seriam típicos da polity:

1. As definições de Estado e nação, tais como o regime republicano ou monárquico, a definição do território, a organização federativa ou unitária, o exercício direto e/ou representativo do poder político pelos cidadãos, a noção de nacionalidade e a estrutura do aparato estatal.

2. Os direitos individuais fundamentais, caracterizados pelas condições básicas do exercício da cidadania individual (direitos civis). Consideramos princípios da polity, nessa primeira classificação geral, as garantias da liberdade civil, que Berlin (1981, pp. 133-145) reuniu sob a expressão "liberdade negativa" (proteção do cidadão contra a ação arbitrária do Estado), e os direitos políticos de participação democrática. Note-se que esse critério minimalista afasta da definição constitucional da polity os direitos substantivos, individuais e sociais, que normalmente vêm acompanhados de normas constitucionais programáticas.

3. As regras do jogo, que organizam os processos de participação e competição políticas, relacionamento entre e intrapoderes, interação entre níveis de governo e entre atores coletivos reconhecidos como lidando com interesses de natureza pública. Tais regras estipulam: (a) a divisão de prerrogativas e funções entre os atores institucionais, (b) as regras operacionais do processo decisório governamental e (c) os tempos e os prazos que balizam tais processos.

Esses três critérios partem da maior generalidade possível da polity (critério 1) e ganham especificidade até quase tocar o nível de policy por duas vezes. Pela primeira vez, quando, no critério 2, a menção à cidadania poder-nos-ia levar a incluir direitos constitucionais substantivos que requerem policies para sua efetivação. Todavia, nessa definição minimalista de polity, evitamos confundir direitos individuais de proteção (contra o Estado e também contra outras pessoas) e de participação na esfera pública, com os direitos de emulação mediante políticas governamentais que visem a atenuar desigualdades socioeconômicas. Nessa classificação inicial, o primeiro tipo de direitos compõe a polity e, portanto, tem natureza constitucional. O segundo aproxima-se da categoria de policy, apesar de sua inclusão na Carta conferir-lhe formalmente status constitucional.

A policy é quase tocada pela segunda vez quando, no critério 3 (regras do jogo), mencionamos as funções dos entes governamentais. Notese que esse critério se destina a catalogar provisões constitucionais que organizam processos como o da divisão de atribuições governamentais específicas entre órgãos estatais - e não devem ser confundidas com dispositivos que estabeleçam funções promocionais do Estado e são classificados como policy. As funções de governo só serão classificadas como polity quando disserem respeito a questões de ordem procedimental, relacionadas à distribuição horizontal de poder entre os diversos entes estatais, ao funcionamento interno desses mesmos entes, à participação democrática dos cidadãos e à garantia de suas liberdades negativas. Funções passíveis de serem classificadas como polity não serão aquelas que se referem a funções emuladoras do Estado, mas aquelas inspiradas nos princípios liberal (do governo limitado) e democrático (do governo participativo). Por outro lado, serão classificadas como policy justamente quando impuserem obrigações positivas ("direito do cidadão, dever do Estado") numa perspectiva vertical de relação entre o governo e a sociedade, em torno de direitos substantivos cuja efetivação depende da implementação de políticas sociais.

Entretanto, desde que Marshall (1967) definiu a composição tripartite da cidadania moderna em direitos civis, políticos e sociais e que os textos constitucionais da segunda metade do século XX estabeleceram um amplo leque de obrigações sociais do Estado, tornou-se bastante difícil defender um conceito de polity tão minimalista como o estabelecido acima. ${ }^{14} \mathrm{Em}$ todos os países que recentemente adotaram o figurino liberal-democrático, gamas importantes de direitos sociais foram mencionadas nos capítulos constitucionais destinados 
aos direitos e às garantias fundamentais. Nossas constituições atuais não se restringem a estabelecer os limites necessários à vigência da "liberdade negativa" e tratam de avançar na direção da igualdade, impondo obrigações positivas ao Estado. É verdade que a realização dessa igualdade é obstada pelo direito também constitucional da propriedade privada, não sendo demais lembrar que tal dispositivo é a pedra angular do Estado de Direito liberal. ${ }^{15}$ De qualquer forma, considera-se um grande salto de cidadania a constitucionalização de direitos de igualdade material entre os homens, mesmo que definições como "função social da propriedade" e "Estado Democrático de Direito" comportem boa dose de contradição, refletida em tensões no interior do texto constitucional.

Por essas razões e apesar de os conceitos de cidadania e polity não designarem a mesma coisa, decidimos trabalhar com dois tipos de classificação: a minimalista, baseada nos três critérios acima, e uma maximalista, que além dos três anteriores, incorporaria um quarto critério, mencionado a seguir:

4. Os direitos materiais orientados para o bemestar e a igualdade, assim como as funções estatais a eles associadas. Tais direitos e funções estatais não se confundem com os três critérios anteriores, dado que não têm implicação direta sobre as definições de Estado e nação, não constituem direitos civis de proteção à liberdade individual, nem direitos políticos de participação democrática, assim como não configuram regras processuais da competição pelo poder ou das relações entre e intra-órgãos governamentais. Todavia, não se trata aqui de fazer mera concessão a uma visão da Constituição como programa social de governo, mas de indicar que determinados direitos materiais podem ser considerados condições básicas para o funcionamento adequado do regime democrático. Tais direitos têm a importante função de promover a adesão ao pacto político democrático e suprimi-los poderia levar a democracia ao colapso. Enquanto os direitos civis de liberdade e políticos de participação mencionados no critério 2 podem ser considerados direitos operacionais fundamentais à vida democrática, os direitos materiais aqui mencionados podem ser considerados direitos condicionantes do jogo político nesses regimes, na medida em que mantêm a adesão social ao pacto político democrático. ${ }^{16}$

Por fim, independentemente do maior peso liberal-democrático ou igualitário das Cartas, normas propriamente constitucionais referem-se apenas a principios fundamentais do ordenamento político, e não a detalhes que são o objeto da politics infraconstitucional cotidiana durante a confecção das policies. A constitucionalização de assuntos que são a matéria-prima do jogo político ordinário extrapolaria justamente o caráter constitucional, conformador do jogo, pois estipularia rigidamente e a priori o que será ou não passível de mudança pela maioria política. Limitando-se em demasia os resultados possíveis do jogo, constrange-se a liberdade dos atores na politics cotidiana, equiparando a polity ao que é considerado policy, primeiramente, pelos próprios contendores políticos. Tendo isto em vista, incluímos dois critérios adicionais para classificar textos constitucionais:

5. Critério de Generalidade. Não serão classificados como polity os dispositivos constitucionais não genéricos (muito específicos). Embora de difícil definição em abstrato, a distinção entre generalidade e especificidade poderia ser determinada da seguinte forma: são específicos os dispositivos derivados de princípios constitucionais superiores, mas cujo conteúdo pode sofrer alterações sem que isso ponha em risco as provisões mais amplas sob os quais esses dispositivos estão abrigados. Essa é uma maneira eficaz de distinguir polity de policy, uma vez que os textos constitucionais contemporâneos tendem, metaforicamente, a assemelhar-se a árvores de cujo tronco saem galhos que se ramificam até os últimos detalhes. Nosso critério de generalidade poderia funcionar à maneira da poda, cortando pontas de galhos sem ameaçar a vida da árvore: igualmente, há dispositivos constitucionais cuja retirada do texto não poria em risco os princípios fundamentais a que estão associados. Isto será particularmente útil na desclassificação da condição de poli- 
ty dos dispositivos que estabelecem regras do jogo, mas que por serem demasiadamente detalhistas, especificando processos que caberiam à normatividade infraconstitucional, poderiam ser "podados" da Constituição sem que a essencialidade do princípio superior fosse afetada.

6. Critério de Controvérsia. Também deixarão de ser classificados como polity dispositivos cujo conteúdo for tipicamente objeto da controvérsia político-partidária cotidiana, dizendo respeito às plataformas governamentais apresentadas pelos partidos em seu embate pelos postos de governo e não se enquadrando, portanto, nas condições que caracterizam dispositivos de tipo constitucional, seja como normas paramétricas da politics, seja como regras definidoras de limiares e limites das policies. Em princípio não serão desclassificados como polity dispositivos constitucionais que estabeleçam regras procedimentais, exceto quando tenham sido inseridos na Carta apensados a um outro dispositivo que é, ele mesmo, policy.

As razões pelas quais adotamos estes dois últimos critérios são as seguintes. Quanto à generalidade, normas muito específicas não constituem parâmetros de funcionamento do sistema político, de desenrolar do jogo e de limitação do escopo das decisões, pois equivalem - de antemão - às próprias decisões que caberia aos atores políticos tomar; por conta disso, não têm caráter constitucional. Ademais, é de se esperar que acabem por criar obstáculos na conjuntura à gestão democrática, na medida em que engessam a ação dos governantes e/ou dos atores sociais diante de situações imprevistas, mudanças de condições sociais e econômicas, novas tecnologias etc. Com isso, a Constituição pode se tornar um instrumento que, em vez de conferir maior segurança jurídica à sociedade, impeça-a de dar cabo de seus problemas em tempo hábil e com a precisão necessária, devido ao congelamento constitucional de temas e problemas próprios da conjuntura e afeitos à ação governamental.

O mesmo se aplica à questão da controvérsia - com um agravante. A constitucionalização de policies reduz em demasia a liberdade decisória dos atores e, portanto, o faz em detrimento da democracia. Afinal, restringe para além do necessário, numa democracia constitucional, a possibilidade de que à alternância dos partidos e das lideranças no governo corresponda uma modificação das políticas públicas implementadas - tendo em vista o leque ideológico e de interesses de uma determinada sociedade num dado momento histórico. Com isso a competição democrática não é impedida no plano eleitoral, mas tem seus efeitos restringidos ou em certa medida anulados no plano governamental. Pode-se supor que é justamente para isto que servem as constituições - restringir a ação dos governos. Mas a suposição é incorreta se não considera que tal restrição, caso ultrapasse certos limites, impede que a própria vontade popular se realize periodicamente mediante as ações de representantes eleitos.

O critério da controvérsia aponta para o fato de que não é legítimo numa democracia constitucionalizar questões que sejam controversas na disputa partidária. A Constituição deve procurar definir (no limite do possível) apenas o que é incontroverso: as condições básicas de funcionamento de um sistema político competitivo. Daí, o que for objeto de disputa deve ser resolvido na disputa, ou seja, nos processo eleitoral e decisório, dentro dos marcos poliárquicos.

Por fim, a excessiva limitação constitucional restringirá ainda mais o alcance das decisões majoritárias ao multiplicar os motivos para que minorias derrotadas recorram à Justiça como forma de obliterar decisões legislativas ordinárias, alegando sua inconstitucionalidade - claro, apenas onde se adote o controle judicial da constitucionalidade das leis. Em suma, a constitucionalização de policies impõe a vontade momentânea de uma maioria conjuntural às maiorias futuras, cerceando-lhes (Cf. Holmes, 1988). O Quadro 2 resume os critérios de classificação do texto constitucional relativos aos dois modelos teorizados nesta seção.

\section{Análise dos resultados ${ }^{17}$}

A versão original da Constituição de 1988 contém 245 artigos. Decompostos em parágrafos, incisos e alíneas, eles se desdobram em 1.627 dis- 


\section{Quadro 2 \\ Critérios de Distinção de Matérias Constitucionais e Não-constitucionais}

\begin{tabular}{|c|c|c|}
\hline & \multicolumn{2}{|c|}{ MODELOS DE CLASSIFICAÇÃO } \\
\hline & Minimalista (liberal clássico) & MAXIMALISTA(social) \\
\hline \multirow{4}{*}{ CRITÉRIOS SUBSTANTIVOS } & $\begin{array}{l}\text { (1) As definições de } \\
\text { Estado e Nação }\end{array}$ & $\begin{array}{l}\text { (1) As definições } \\
\text { de Estado e Nação }\end{array}$ \\
\hline & $\begin{array}{l}\text { (2) Os direitos } \\
\text { individuais fundamentais }\end{array}$ & $\begin{array}{l}\text { (2) Os direitos } \\
\text { individuais fundamentais }\end{array}$ \\
\hline & (3) As regras do jogo & (3) As regras do jogo \\
\hline & - & $\begin{array}{l}\text { (4) Os direitos materiais } \\
\text { e funções estatais correlatas }\end{array}$ \\
\hline \multirow{2}{*}{ CRITÉRIOS FORMAIS/OPERACIONAIS } & (5) Generalidade & (5) Generalidade \\
\hline & (6) Controvérsia & (6) Controvérsia \\
\hline
\end{tabular}

positivos. Para efeitos desta primeira contabilidade do texto constitucional, preferimos excluir o Ato das Disposições Constitucionais Transitórias (ADCT), por sua natureza específica de regra de transição. ${ }^{18}$ Depois de rigoroso exame de cada um dos 1.627 dispositivos da Carta original e aplicação da Metodologia de Análise Constitucional (MAC), concluímos que 30,5\% deles podem ser classificados seguramente como policy e 69,5\% dizem respeito a normas de caráter constitucional - polity (ver Tabela 1).

\section{Dispositivos de polity}

O Gráfico 1 apresenta a distribuição de dispositivos de polity e policy ao longo dos nove títulos que compõem a Constituição. Em termos gerais, deve-se destacar que o título "Da organização dos poderes" é responsável por quase $1 / 3$ do total de dispositivos da Carta, indicando que os constituintes de 1988 tiveram grande preocupação em estabelecer minuciosamente a dimensão horizontal e funcional do sistema político brasileiro: composição, competências, prerrogativas e regras de funcionamento dos poderes Executivo, Legislativo, Judiciário e órgãos auxiliares como o Ministério Público, a Advocacia-Geral da União, entre outros. O segundo maior é o título "Da organização do Estado", que estabelece a estrutura político-administrativa do país, enfatizando a dimensão do federa-
Tabela 1

Constituição: polity ou policy?

\begin{tabular}{c|c|c}
\hline & Freq. & $\%$ \\
\hline Polity & 1.131 & 69,5 \\
\hline Policy & 496 & 30,5 \\
\hline TOTAL & 1.627 & 100 \\
\hline
\end{tabular}

lismo, dos governos subnacionais e de suas relações com a União. Apenas em terceiro lugar, praticamente empatados, aparecem os títulos "Direitos e garantias fundamentais" e "Ordem Social", responsáveis justamente pelos elementos mais concretos e definidores da cidadania civil, política e social brasileira.

A Tabela 2 apresenta um novo perfil da Constituição, mais revelador do que a topografia aparente dos títulos formais. Com base na aplicação dos quatro critérios formulados pela MAC, foi possível revelar que mais da metade dos dispositivos de polity da Carta de 1988 (55,3\%) diz respeito a regras do jogo, estabelecendo a divisão de prerrogativas e funções entre os atores institucionais, os mecanismos operacionais do processo decisório governamental e os tempos e prazos que balizam tais processos. Quanto aos aspectos que poderíamos definir como ainda mais estruturais ou estáticos do ordenamento constitucional - as "definições de Estado e nação” -, estes ocuparam apenas 6,5\% do texto promulgado em 1988. 
Tabela 2

Tipos de Polity

\begin{tabular}{l|r|c}
\hline & Freq. & $\%$ \\
\hline 1. Definições de Estado e Nação & 74 & 6,5 \\
\hline 2. Direitos individuais & 92 & 8,1 \\
\hline 3. Regras do jogo & 625 & 55,3 \\
\hline 4. Direitos materiais & 65 & 5,7 \\
\hline
\end{tabular}

DisPOSITIVOS COM MAIS DE UM SENTIDO

\begin{tabular}{l|r|c}
\hline Definição de Estado e Nação + & & \\
\hline Regras do Jogo & 160 & 14,1 \\
\hline $\begin{array}{l}\text { Direitos individuais + } \\
\text { Regras do Jogo }\end{array}$ & 48 & 4,2 \\
\hline Outros dispositivos duplos & 58 & 5,1 \\
\hline Outros dispositivos triplos & 8 & 0,8 \\
\hline Dispositivo quádruplo & 1 & 0,1 \\
\hline TotaL & 1.131 & 100 \\
\hline
\end{tabular}

Em 24,3\% dos dispositivos constitucionais de tipo polity detectamos mais de um sentido normativo, isto é, tais dispositivos contemplam mais de um dos quatro critérios formulados pela MAC, com destaque também para a presença de regras do jogo na maior parte deles: 230 dos 275 dispositivos de polity duplos, triplos ou quádruplos contém regras do jogo, simultaneamente a outro(s) dos três critérios de classificação.

Em suma, observamos que 855 ou $75,5 \%$ dos dispositivos de polity da Carta brasileira dizem respeito - exclusivamente ou em associação com outros - a definições de regras do jogo.

Uma primeira conclusão a extrair desse resultado é que, se a Constituição brasileira pode ser considerada muito extensa, seu tamanho reflete o nível de detalhamento atingido pela Constituinte na definição dos procedimentos que deveriam presidir o funcionamento da democracia vindoura, algo que certamente pode ser explicado pelas preocupações da época em torno da libera-

\section{Gráfico 1}

\section{Polity ou policy, nos Nove Títulos da Constituição de 1988}

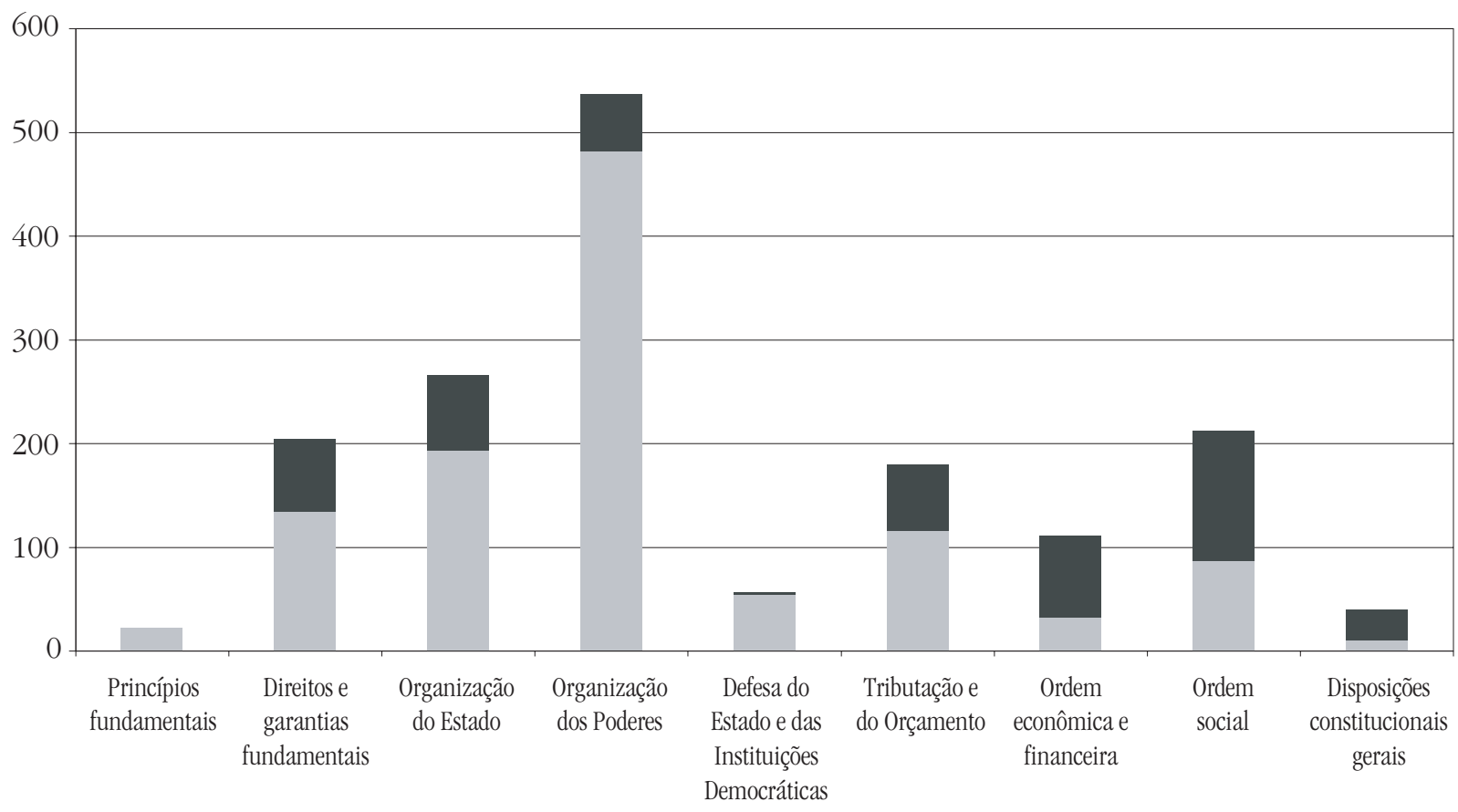


lização e da redemocratização do regime político. Por outro lado, se Ulysses Guimarães alcunhou o texto como "Constituição Cidadã", o adjetivo perde força aos verificarmos que, quantitativamente, os componentes sociais, civis e políticos da cidadania são incomparavelmente inferiores à dimensão das regras do jogo: apenas 5,7\% dos dispositivos constitucionais dizem respeito a direitos materiais de bem-estar e igualdade social, ao passo que somente $8,1 \%$ concernem a direitos individuais de liberdade e de participação política. Somados, os dispositivos "cidadãos" perfazem pouco mais de 13\% da Carta de 1988.

O Tabela 3 apresenta o perfil dos dispositivos de polity no interior de cada título da Constituição, à luz dos quatro critérios da MAC. Como era de se esperar, a Carta abre majoritariamente com "Definições de Estado e de Nação" no seu primeiro título, embora este contenha também um pouco de "direitos individuais fundamentais" e outros dispositivos que combinam de dois a três tipos de polity. O segundo título, como o próprio nome indica, contém majoritariamente "direitos individuais fundamentais", ladeados por um pouco de "direitos materiais" e também de "regras do jogo". O terceiro título, "Organização do Estado", traz dispositivos que criam estrutura estatal e simultaneamente introduzem regras do jogo para o seu funcionamento, especialmente no que diz respeito à dimensão federativa.

Previsivelmente, no título "Da organização dos Poderes" predominam regras do jogo. O título IV, que é o maior e talvez mais importante da Carta (por definir o modus operandi das instituições que compõem o regime democrático brasileiro), estrutura detalhadamente os três Poderes de Estado e alguns organismos paralelos e auxiliares (Conselho da República, Conselho de Defesa Nacional, Ministério Público, Advocacia Geral da União e Defensoria Pública). Além de definir a organização e as atribuições do Legislativo, do Executivo, do Judiciário e do Ministério Público, estabelece condições de elegibilidade e de investidura nas respectivas carreiras públicas, bem como normas relativas ao exercício do cargo (mandatos, imunidades, responsabilidades etc.); estabelece regras para o processo Legislativo, a fiscalização financeira e orçamentária do governo e outros procedimentos para o controle recíproco entre os poderes; chega a detalhes na organização do Judiciário federal e impõe linhas gerais para a organização do Judiciário nos estados.

Tabela 3. Composição dos Títulos da Constituição, por tipos de Polity

\begin{tabular}{c|c|c|c|c|c|c|c|c|c}
\hline & $\begin{array}{c}\text { Princípios } \\
\text { fundamen- } \\
\text { tais }\end{array}$ & $\begin{array}{c}\text { Direitos e } \\
\text { garantias } \\
\text { fundamen- } \\
\text { tais }\end{array}$ & $\begin{array}{c}\text { Organização } \\
\text { do Estado }\end{array}$ & $\begin{array}{c}\text { Organização } \\
\text { dos Poderes }\end{array}$ & $\begin{array}{c}\text { Defasa do } \\
\text { Instituiçóes } \\
\text { Democráticas }\end{array}$ & $\begin{array}{c}\text { Tributação } \\
\text { e do } \\
\text { Orçamento }\end{array}$ & $\begin{array}{c}\text { Ordem } \\
\text { econômica } \\
\text { e financeira }\end{array}$ & $\begin{array}{c}\text { Ordem } \\
\text { social }\end{array}$ & $\begin{array}{c}\text { Disposições } \\
\text { constitu- } \\
\text { cionais } \\
\text { gerais }\end{array}$ \\
\hline $\begin{array}{c}\text { Definições de } \\
\text { Estado e Nação }\end{array}$ & $40,9 \%(9)$ & $7,5 \%(10)$ & $10,9 \%(21)$ & $5,0 \%(24)$ & $9,3 \%(5)$ & $0,0 \%(0)$ & $15,6 \%(5)$ & $0,0 \%(0)$ & $0,0 \%(0)$ \\
\hline $\begin{array}{c}\text { Direitos } \\
\text { individuais } \\
\text { fundamentais }\end{array}$ & $18,2 \%(4)$ & $44,0 \%(59)$ & $0,5 \%(1)$ & $0,0 \%(0)$ & $9,3 \%(5)$ & $1,7 \%(2)$ & $18,8 \%(6)$ & $17,4 \%(15)$ & $0,0 \%(0)$ \\
\hline $\begin{array}{c}\text { Regras } \\
\text { do jogo }\end{array}$ & $0,0 \%(0)$ & $14,9 \%(20)$ & $28,5 \%(55)$ & $82,4 \%(397)$ & $53,7 \%(29)$ & $87,1 \%(101)$ & $9,4 \%(3)$ & $10,5 \%(9)$ & $100,0 \%(11)$ \\
\hline $\begin{array}{c}\text { Direitos } \\
\text { materiais }\end{array}$ & $0,0 \%(0)$ & $13,4 \%(18)$ & $0,5 \%(1)$ & $0,0 \%(0)$ & $0,0 \%(0)$ & $0,0 \%(0)$ & $18,8 \%(6)$ & $46,5 \%(40)$ & $0,0 \%(0)$ \\
\hline $\begin{array}{c}\text { Estado e Nação } \\
\text { + Regras } \\
\text { do Jogo }\end{array}$ & $9,1 \%(2)$ & $0,7 \%(1)$ & $51,3 \%(99)$ & $10,6 \%(51)$ & $1,9 \%(1)$ & $2,6 \%(3)$ & $9,4 \%(3)$ & $0,0 \%(0)$ & $0,0 \%(0)$ \\
\hline $\begin{array}{c}\text { Outros princí- } \\
\text { pios duplos }\end{array}$ & $27,3 \%(6)$ & $19,4 \%(26)$ & $7,3 \%(14)$ & $2,1 \%(10)$ & $25,9 \%(14)$ & $8,6 \%(10)$ & $25,0 \%(8)$ & $20,9 \%(18)$ & $0,0 \%(0)$ \\
\hline $\begin{array}{c}\text { Outros } \\
\text { princípios }\end{array}$ & $4,5 \%(1)$ & $0,0 \%(0)$ & $1,0 \%(2)$ & $0,0 \%(0)$ & $0,0 \%(0)$ & $0,0 \%(0)$ & $3,1 \%(1)$ & $4,7 \%(4)$ & $0,0 \%(0)$ \\
\hline \begin{tabular}{c} 
Total \\
\hline
\end{tabular} & $100,0 \%(22)$ & $100,0 \%(134)$ & $100,0 \%(193)$ & $100,0 \%(482)$ & $100,0 \%(54)$ & $100,0 \%(116)$ & $100,0 \%(32)$ & $100,0 \%(86)$ & $100,0 \%(11)$ \\
\hline
\end{tabular}


O título $\mathrm{V}$ reúne dispositivos que ascenderam a tal ponto da topografia constitucional, provavelmente por terem como elemento principal as Forças Armadas. Refletindo o peso político remanescente dos militares à época da Constituinte, não só se manteve o status constitucional diferenciado para as Forças Armadas, como também, preservando a tradição, disciplinaram-se a seu lado os mecanismos de "Defesa do Estado e das instituições democráticas" (nome do título V), a saber, a Segurança Pública e os Estados de Defesa e de Sítio. Noutro contexto de transição democrática possivelmente tais elementos dispersar-se-iam (submetidos normativamente) a outros títulos constitucionais. Seja como for, por estabelecer condições da decretação dos Estados de Defesa e de Sítio, o título também reúne boa soma de dispositivos classificados como regras do jogo.

Ao estabelecer princípios de "Tributação e orçamento" no título VI, os constituintes também instituíram um detalhado conjunto de regras do jogo sobre a conduta governamental em relação às finanças públicas. Mais do que isso, a maior parte dos dispositivos foi assim classificada por se referir ao pacto federativo em torno das possibilidades de tributar e dos princípios de repartição das receitas tributárias. A dimensão federativa tem um peso excepcional em todo o texto constitucional e essa é uma das principais explicações para o grande número de dispositivos de polity do tipo regras do jogo, dispersos por vários títulos e seções da Carta de 1988.

Embora menor do que os demais na proporção de polity, o título VII contempla um pouco de cada um dos quatro princípios definidos pela MAC. Já no título VIII predominam os "direitos materiais" até porque ele trata "Da ordem social". Por fim, os poucos dispositivos classificados como polity, presentes no último título da Carta e destinados a aspectos gerais, dizem respeito, na sua totalidade, a regras do jogo.

\section{Dispositivos de policy}

Excetuado o título relativo aos "Princípios fundamentais" (por sinal o menor deles, com apenas 22 dispositivos), encontramos dispositivos de policy em todos os demais. Percentualmente, os títulos das "Disposições constitucionais gerais" e da "Ordem econômica e financeira" foram os que apresentaram maior freqüência de policy, com aproximadamente $70 \%$ do total de dispositivos (ver Gráfico 2). Na seqüência, figura o título da "Ordem social", no qual cerca de $60 \%$ dos dispositivos contemplam policy e não polity. Nada menos que $1 / 3$ do título "Da tributação e do orçamento" e até mesmo do título "Direitos e garantias fundamentais" não contemplam matérias de natureza constitucional, pois se referem a policy e não a polity. Enfim, mesmo títulos referidos às linhas básicas do moderno constitucionalismo - "Da organização do Estado" e "Da organização dos poderes" - revelaram a existência de dispositivos policy em seu interior: o primeiro com taxa de $27 \%$ e o segundo com taxa de $10 \%$ do total de dispositivos.

Como mostra a Tabela 4, dos 496 dispositivos classificados como policy, 205 deles (41,3\%) sequer têm relação com os quatro princípios constitucionais definidos pela MAC e podem, portanto, ser considerados políticas públicas em estado puro. Logo, poderiam tranqüilamente integrar a agenda legislativa ordinária de qualquer governo, sem afetar quaisquer dos princípios. Outros 43,5\% dos dispositivos de policy da Constituição ao menos tangenciam um dos quatro critérios, mas sua especificidade é tamanha que caberia à lei complementar ou ordinária discipliná-los. Pelo critério de controvérsia, 35 dispositivos que remetem a aspectos de polity foram desclassificados de tal condição, justamente por constitucionalizarem aspectos que estão longe do consenso básico característico de regras constitucionais. Ocorre que, ao resguardá-los sob o manto protetor da Constituição, os constituintes retiraram de futuras maiorias políticas ordinárias o direito de adotar soluções alternativas, tão razoáveis - porém controversas - quanto as estabelecidas pela Carta. Outros quarenta dispositivos foram classificados como policy por serem simultaneamente específicos e controversos.

A Tabela 5 traz a exata medida da agenda legislativa futura (de tipo complementar ou ordinário) criada pela Constituição: 379 dispositivos ou $23,3 \%$ da Carta fixaram a necessidade de lei federal para regulamentar ou garantir a efetividade de princípios constitucionais. Uma tarefa de pesquisa empírica é verificar em que medida as 
Gráfico 2

Polity ou Policy nos Nove Títulos da Constituição (em \%)

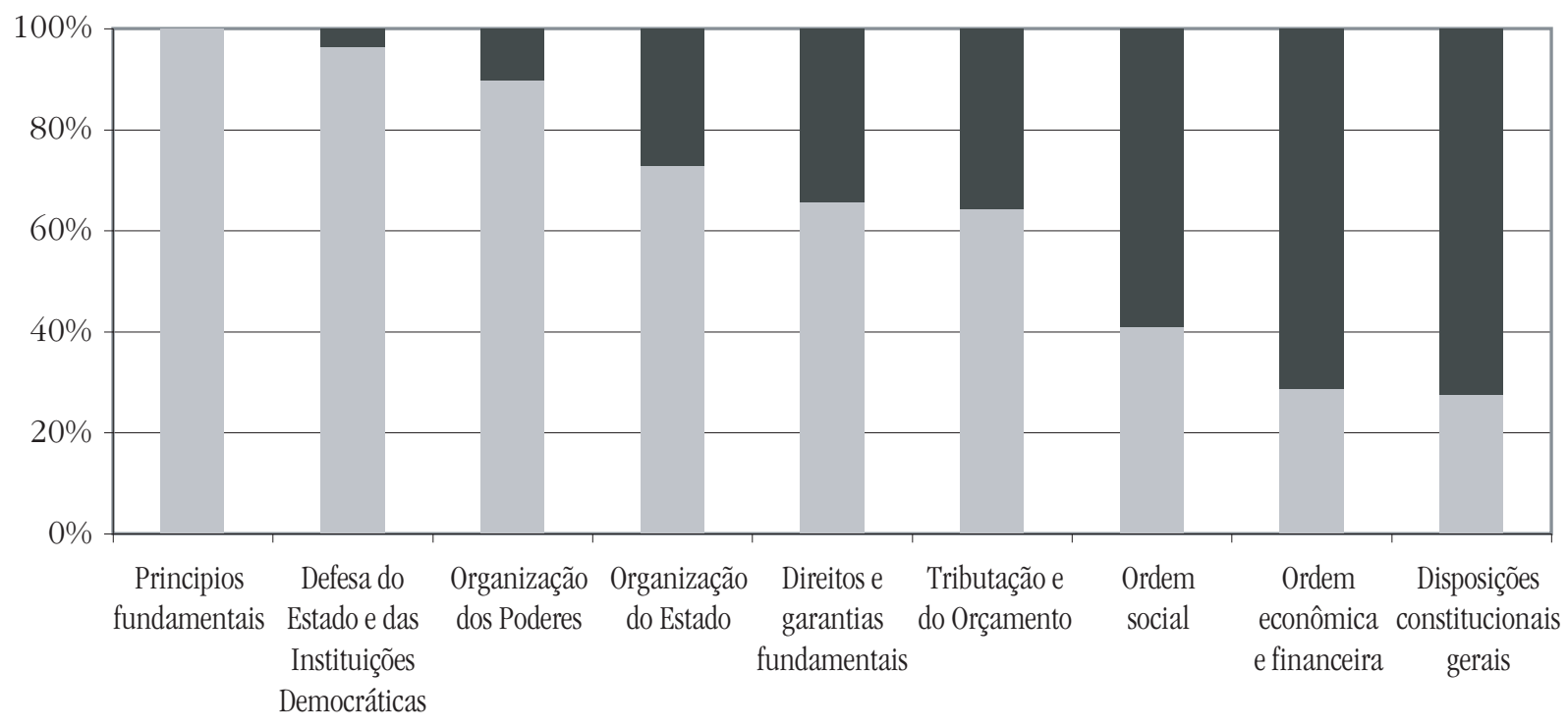

Polity Policy

Tabela 4

Por que Policy?

\begin{tabular}{l|r|r}
\hline & Freq. & $\%$ \\
\hline Policy pura & 205 & 41,3 \\
\hline Policy por especificidade & 216 & 43,5 \\
\hline Policy por controvérsia & 35 & 7,1 \\
\hline $\begin{array}{l}\text { Policy por especificidade } \\
\text { e controvérsia }\end{array}$ & 40 & 8,1 \\
\hline TOTAL & 496 & 100 \\
\hline
\end{tabular}

legislaturas posteriores lograram cumprir essa missão e quantos dos 379 dispositivos foram de fato complementados e/ou regulamentados por normatização infraconstitucional. Outros poucos dispositivos remetem a leis federais e estaduais.

Um último dado interessante, mostrado na Tabela 6, é que a Constituição de 1988 contém auto-referências em 12,4\% dos seus dispositivos, os quais remetem a outros pontos da própria Carta. Uma pequena quantidade faz remissão inclusive a determinados aspectos das constitui- ções estaduais que iriam ser elaboradas na seqüência da federal.

\section{Constituição e reforma constitucional}

Uma das principais motivações deste estudo reside na tentativa de mensurar o impacto do perfil da Carta constitucional sobre o processo governamental, a elaboração legislativa e a produção de

\section{Tabela 5}

Dispositivos que Remetem à Legislação

\begin{tabular}{l|r|r}
\hline & Freq. & $\%$ \\
\hline Remetem à lei federal & 379 & 23,3 \\
\hline Remetem à lei estadual & 2 & 0,1 \\
\hline Remetem à lei municipal & 1 & 0,1 \\
\hline Remetem a leis federal e estadual & 9 & 0,5 \\
\hline Remetem a leis federal e municipal & 1 & 0,1 \\
\hline Não remetem à lei & 1.235 & 75,9 \\
\hline TOTAL & 1.627 & 100 \\
\hline
\end{tabular}


Tabela 6

Dispositivos que Remetem à Constituição

\begin{tabular}{l|r|r}
\hline & Freq. & $\%$ \\
\hline Remetem à própria Carta & 202 & 12,4 \\
\hline Remetem à Constituição estadual & 5 & 0,3 \\
\hline Remetem a ambas & 1 & 0,1 \\
\hline Não fazem remissão & 1.419 & 87,2 \\
\hline TOTAL & 1.627 & 100 \\
\hline
\end{tabular}

políticas públicas. A pergunta subjacente a esse objetivo segue sendo a mesma, desde que nos aproximamos do tema pela primeira vez: afinal, por que a Constituição brasileira de 1988 não teria conseguido se estabilizar e por que todos os governos posteriores se esforçaram por modificála em diversos aspectos? No trabalho anterior (Couto e Arantes, 2003) em que aplicamos a MAC ao conjunto de emendas constitucionais promulgadas durante os dois mandatos do presidente Fernando Henrique Cardoso, chegamos a resultados surpreendentes:

1. Dos 482 dispositivos de emendas que modificaram ou aglutinaram novos elementos constitucionais, nada menos que 68,8\% (332) eram de policy e apenas 31,2\% (150) eram de polity.

2. Do total de dispositivos de emendas constitucionais, 60,8\% eram aglutinadores, isto é, vieram agregar novos aspectos à Constituição. Dentre os aglutinadores, nada menos que $82,7 \%$ diziam respeito a policy e apenas $17,9 \%$ acrescentaram mais polity à Carta.

3. A conclusão geral a que chegamos naquele estudo foi que, ao contrário do que se afirmava no debate público, nossa Constituição não fora mutilada pelas emendas constitucionais do período FHC. Pelo contrário, graças a elas, a Carta cresceu nada menos que 15,3\%, o dobro da taxa de modificação do texto original, nesse mesmo período, que foi de apenas $8,8 \%$.

Em suma, o crescimento do texto constitucional no período FHC foi marcado pela inclusão de novos dispositivos de policy na Constituição, em proporção significativamente superior aos dispositivos de polity incluídos. Compreender precisamente por que isso ocorreu segue sendo um desafio analítico e de pesquisa empírica. Nessa perspectiva, verificamos com maior acuidade sobre o que incidiram as emendas que visaram a modificar aspectos do texto constitucional (se polity ou policy). O resultado encontra-se na Tabela 7 .

Tabela 7

Constituição e Emendas Constitucionais - FHC

\begin{tabular}{l|c|c}
\hline \multicolumn{3}{c}{ Dispositivos constitucionais } \\
\hline $\begin{array}{l}\text { Tipo de dispositivo } \\
\text { original }\end{array}$ & $\begin{array}{c}\text { Sofreram } \\
\text { modificação }\end{array}$ & $\begin{array}{c}\text { Não sofreram } \\
\text { modificação }\end{array}$ \\
\hline Polity & 92 & 1.039 \\
\hline Policy & 68 & 428 \\
\hline Total & 160 & 1.467 \\
\hline
\end{tabular}

Embora o maior número de emendas modificadoras tenha incidido sobre dispositivos de polity do texto original, proporcionalmente é bem mais significativo o número de emendas sobre dispositivos de policy, se considerarmos o perfil geral da Constituição. O fato é que teste estatístico ${ }^{19}$ rejeitou a hipótese de independência entre as variáveis da tabela, revelando que existe uma associação entre policy constitucionalizada e emendas modificadoras. Noutras palavras, as mudanças constitucionais do período FHC incidiram mais significativamente sobre dispositivos de policy do que em dispositivos de polity, o que corrobora a hipótese com a qual estamos trabalhando desde o início: a agenda política e governamental brasileira segue sendo uma agenda constituinte, não porque sucessivos presidentes quiseram mutilar os princípios fundamentais ou por outra razão exógena, mas porque a própria Carta os obrigou a alterar a Constituição para implementar as políticas públicas. Mais do que isso, o grande legado constitucional da era FHC foi ter acrescentado 250 novos dispositivos de policy à Carta brasileira, constitucionalizando mais a agenda governamental e estendendo o desafio de formar coalizões legislativas majoritárias à base de $3 / 5$ aos governos posteriores. 


\section{BIBLIOGRAFIA}

ACKERMAN, B. (1988), Neo-federalism?, in J. Elster e R. Slagstad (eds.), Constitutionalism and democracy, Cambridge: Cambridge University Press.

ARANTES, Rogério Bastos. (1997), Judiciário e política no Brasil. São Paulo, Sumaré/ Educ/Fapesp.

ARANTES, Rogério Bastos \& KERCHE, Fábio J. (1999), "Judiciário e democracia no Brasil". Novos Estudos, 54: 27-41, jul., São Paulo, Cebrap.

BERLIN, Isaiah. (1981), Quatro ensaios sobre a liberdade. Brasília, Editora da UnB.

BUCHANAN, J. M. \& Tullock, G. (1999 [1962]), The calculus of consent: logical foundations of constitutional democracy. Indianapolis, Liberty Fund.

COELHO, João G. Lucas \& OlIVEIRA, Antonio C. Nantes. (1989), A nova Constituição: avaliação do texto e perfil dos constituintes. Rio de Janeiro, Inesc/Revan.

COUTO, Cláudio Gonçalves. (1997), "A Agenda constituinte e a difícil governabilidade". Lua Nova - Revista de Cultura e Política, 39: 33-52. São Paulo, CEDEC, 1997.

(1998), "A longa Constituinte: reforma do Estado e fluidez institucional no Brasil". Dados, 41 (1): 51-86.

(2001), "O avesso do avesso: conjuntura e estrutura na recente agenda política brasileira". Revista São Paulo em Perspectiva, 15 (4): 32-44, São Paulo, Seade.

(2005), "Constituição, competição e políticas públicas". Lua Nova - Revista de Cultura e Política, 65: 95-135, maio-ago.

COUTO, Cláudio Gonçalves \& ARANTES, Rogério Bastos. (2003), "¿Constitución o políticas públicas? Una evaluación de los años FHC", in Vicente Palermo, Politica brasileña contemporánea: de Collor a Lula en años de transformación, Buenos Aires, Siglo Veintiuno Editores.
DAHL, R. A. (1997), Poliarquia: participação e oposição. São Paulo, Edusp.

DI RUFFÌA, Paolo Biscaretti. (1996), Introducción al derecho constitucional comparado. México, Fondo de Cultura Económica.

FIOCCA, Demian \& GRAU, Eros (orgs.). (2001), Debate sobre a Constituição de 1988. São Paulo, Paz e Terra.

HOLMES, Stephen. (1988), "Precommitment and the paradox of democracy", in Jon Elster e Rune Slagstad, Constitutionalism and democracy, Cambridge: Cambridge University Press.

HOLMES, Stephen \& SUNSTEIN, Cass. (1995), "The politics of constitutional revision in Eastern Europe", in Sanford Levinson (ed.). Responding to imperfection: the theory and practice of constitutional amendment, Princeton, Princeton University Press.

(1999), The cost of rights: why liberty depends on taxes. Nova York, W.W. Norton.

LAMOUNIER, Bolívar (org.). (1990), De Geisel a Collor: o balanço da transição. São Paulo, Idesp/Sumaré.

LASSALLE, Ferdinand. (2000), A essência da constituição. Rio de Janeiro, Lumen Juris.

LEVINSON, Sanford (ed.). (1995), Responding to imperfection: the theory and practice of constitutional amendment. Princeton, Princeton University Press.

LIJPHART, A. (1989), As democracias contemporâneas. Lisboa, Gradiva.

LUTZ, Donald S. (1995), "Toward a theory of Constitutional amendment", in Sanford Levinson (ed.), Responding to imperfection: the theory and practice of constitutional amendment, Princeton, Princeton University Press.

MARSHALL, T. H. (1967), "Cidadania e classe social", in T. H. Marshall, Cidadania, classe social e status, Rio de Janeiro, Zahar. 
MELO, Marcus A. (2002), Reformas constitucionais no Brasil: instituições politicas e processo decisório. Rio de Janeiro/Brasília, Revan/Ministério da Cultura.

MURPHY, Walter F. (1995), "Merlin's memory: the past and future imperfect of the once and future polity", in Sanford Levinson (ed.), Responding to imperfection: the theory and practice of constitutional amendment, Princeton, Princeton University Press.

SARTORI, G. A. (1994), Teoria da democracia revisitada. São Paulo, Ática, 2 vols.

SCHMITT, Carl. (1982), Teoría de la constitución. Madrid, Alianza.

SCHUMPETER, Joseph. (1980), Capitalismo, socialismo e democracia. Rio de Janeiro, Zahar.

SUNSTEIN, Cass. (2001), Designing democracy: what constitutions do. Oxford/Nova York, Oxford University Press.

TSEBELIS, G. (1997), "Processo decisório em sistemas políticos: veto players no presidencialismo, parlamentarismo, multicameralismo e pluripartidarismo". Revista Brasileira de Ciências Sociais, 12 (34): 89-117.

WALDRON, Jeremy. (1999), Law and disagreement. Oxford, Clarendon Press.

\section{Notas}

1 Poder-se-ia alegar que a opção pela modificação constitucional se dá por equívoco, e já houve críticos que afirmaram ser a opção pela emenda constitucional um engano dos governos, sendo possível levar adiante iniciativas por meio de legislação ordinária. Todavia, parece pouco plausível que um governo não disponha de informação e conhecimento suficientes acerca dos procedimentos exigidos em cada caso, a ponto de optar pela via mais difícil para implementar sua agenda, mobilizando todos os recursos necessários para percorrê-la. Para uma discussão sobre os diferentes instrumentos decisórios à disposição dos governos, ver Couto (2001).

2 Souza e Lamounier, "A feitura da nova Constituição: um reexame da cultura política brasileira”, em Lamounier (1990).
3 O texto elaborado pela Comissão Especial de Estudos Constitucionais (Comissão Afonso Arinos) foi descartado pelo presidente José Sarney.

4 Em sua obra clássica de teoria constitucional, Schmitt (1982) aponta que a Constituição de Weimar continha diversos dispositivos que não mereceriam o qualificativo de constitucionais, mas que ali foram introduzidos pela oportunidade que alguns grupos tiveram de cristalizar constitucionalmente seus interesses particulares.

5 Segundo Melo (2002), "Instalada em 13 de outubro de 93 e encerrada em 31 de maio de 94, a revisão, ao longo de 80 sessões, votou apenas 19 mudanças, das quais 12 foram rejeitadas já no primeiro turno das votações. Das 17 mil emendas relatadas - ou melhor, simplesmente ignoradas - pelo relator, deputado Nelson Jobim, apenas seis foram aprovadas. Destas últimas, a única emenda relevante é a que reduziu o mandato do Presidente da República, de cinco para quatro anos" (2002, p. 60).

6 Vale ressaltar um aspecto formal relevante, a saber, uma revisão constitucional é, em princípio, um processo promotor de mudanças muito mais fundamentais do texto constitucional originário do que o são emendas constitucionais. Nos termos de Murphy: "A palavra emendar vem do latim emendere, que significa corrigir ou aprimorar; emendar não significa 'desconstituir ou reconstituir', substituindo um sistema por outro ou abandonando os seus princípios primários. Portanto, mudanças que viessem a transformar uma polity numa outra espécie de sistema político não seriam emendas, absolutamente, mas revisões, ou transformações" (1995, p. 177). Desse ponto de vista, é curioso que no Brasil a revisão constitucional fosse percebida como uma oportunidade de fazer avançar uma agenda governamental.

7 Ao referir-se a este período, afirma Marcus Melo: "Ao contrário da revisão constitucional, o Congresso, na reforma em curso [1995-1996], tipicamente reagiu às iniciativas que partiram do Executivo. Os ministros se tornaram policy advocates das propostas. O Executivo deteve, assim, o poder de agenda durante a reforma" (2002, p. 73). Ou ainda, "embora o arranjo institucional que prevaleceu tenha sido - em seu conjunto - menos favorável à mudança, os fatores contextuais favoreceram amplamente o processo de mudança. Na reforma constitucional [1995-1996], apesar de a rotina utilizada exigir quorum qualificado, tramitação longa e processo descentralizado, o poder de agenda do Executivo, num quadro de desi- 
deologização da agenda pública e ausência de constrangimentos eleitorais decisivos, favoreceu o governo" (Idem, p. 76).

8 As noções de direitos fundamentais operacionais e condicionantes são estipuladas em Couto (2005). Voltaremos a elas mais adiante.

9 Embora numa perspectiva mais filosófica e menos institucional do que a adotada aqui, Sartori analisa a questão do consenso na democracia também em três níveis, do mais básico ao mais superficial: 1. o nível básico que diz respeito ao consenso sobre valores supremos (tais como a liberdade e a igualdade) que habitam a cultura política; 2 . o nível procedimental de consenso em torno das regras do jogo político, indispensável ao funcionamento da democracia; e 3. o nível programático do processo político, marcado pela discussão sobre governos específicos e suas políticas públicas, âmbito no qual o consenso, se houver, está em permanente tensão e ajuste decorrentes do debate acerca das ações políticas concretas. Em outras palavras, esse terceiro nível está mais para o dissenso (que não ameaça o edifício institucional da democracia se o consenso procedimental estiver consolidado) do que para o consenso (ver Sartori, 1994, vol. 1, pp. 127-132). Para uma discussão sobre os limites constitucionais acerca das políticas públicas, ver Couto (2005).

10 Decidimos recorrer ao inglês para esta terminologia pelo fato de que a utilização de termos em português perderia em clareza e precisão. Não há termo em nossa língua que seja equivalente a polity. Mesmo a expressão politéia, roubada ao grego, não é de uso corrente e sequer consta dos principais dicionários. No que diz respeito a politics e policy, a palavra em português é a mesma para ambas: política. Neste caso, precisaríamos falar o tempo todo em "política" como atividade, e em "política pública", ou "política governamental", ou ainda em "políticas". Por uma questão de economia de linguagem e clareza, optamos pelos termos em inglês.

11 Afirmamos serem estes princípios apenas relativamente neutros por considerar que algumas garantias constitucionais dadas a determinados setores de uma sociedade, tendo caráter particular, afetam desigualmente os diversos segmentos que a compõem. Todavia, considerando-se que a derrogação de tais garantias implicaria numa derrocada de toda a ordem constitucional, pode-se afirmar a sua neutralidade nos marcos da ordem social instituida, ou seja, num âmbito que esteja aquém de qualquer transformação de tipo revolucionário. O tratamento clássico dessa questão foi dado por Lassalle (2000).

12 O tema do emendamento constitucional é extensivamente tratado, por diversos autores, no volume editado por Sanford Levinson (1995). Particularmente relevantes para nossa discussão são os capítulos de Lutz (1995) e Holmes e Sunstein (1995).

13 Uma posição filosófica bastante crítica da necessidade de que haja um texto constitucional resguardado das vontades majoritárias é advogada por Waldron (1999). Ele afirma que um sistema puramente majoritário, como o britânico, garante resultados melhores do ponto de vista democrático. Como decorrência de sua posição, Waldron também será bastante crítico do papel exercido pelos tribunais no controle da constitucionalidade das leis. Por outro lado, para uma defesa filosófica já clássica de regras restritivas para uma constituição, ver Buchanan e Tullock (1999 [1962]).

14 Para uma análise da evolução do constitucionalismo moderno e do perfil das constituições adotadas ao longo do século XX, numa perspectiva comparada, ver Di Ruffia (1996).

15 Stephen Holmes e Cass Sunstein (1999) apontam que todos os direitos têm custos, de modo que não só os direitos sociais, mas também os direitos liberais clássicos requerem ações efetivas do Estado (policies) para sua implementação e, portanto, dependem da capacidade que tem o governo de financiar sua implementação. Sunstein (2001) vai ainda mais longe nessa argumentação, mostrando que é possível aos tribunais assegurar o enforcement de direitos sociais. Para tanto, faz uma interessante análise do caso sul-africano, que apresentaria uma constituição de tipo transformativo, em vez de apenas preservativo.

16 Estamos tratando dos direitos sociais, mas também alguns outros direitos são condicionantes. É o caso do direito de propriedade, que não se enquadra na categoria de direito social de Marshall (e sim na de direito civil), mas se constitui num condicionante óbvio para o funcionamento de quaisquer regimes políticos em sociedades capitalistas. Para a distinção entre direitos condicionantes e operacionais, ver Couto (2005).

17 Trata-se de uma primeira análise, de tipo descritivo, dos principais resultados da aplicação da Metodologia de Análise Constitucional. Questões analíticas de fundo, como por exemplo o impacto sobre o processo decisório e sobre o funcio- 
namento das instituições, receberão tratamento mais aprofundado em trabalho futuro.

18 A versão original do ADCT compreende setenta artigos ou 228 dispositivos. Em linhas gerais, trata de regras transitórias em três sentidos básicos: 1) estabelece que situações jurídicas já consolidadas remanescerão no interior do novo ordenamento jurídico, a despeito de ter sido introduzido tratamento diferenciado sobre a matéria pela Constituição recém-promulgada; 2) define procedimentos, prazos e metas de transição para temas específicos contidos na nova Carta; e 3) estabelece situações transitórias no sentido de provisórias, isto é, que desaparecerão gradualmente com a implantação do novo texto constitucional. Por essas razões, consideramos que o ADCT merece classificação à parte, já que tais especificidades podem ter impacto distinto sobre o processo decisório governamental.

19 Teste qui-quadrado, nível de significância de 5\%. 


\section{CONSTITUIÇÃO, GOVERNO E DEMOCRACIA NO BRASIL}

\section{Cláudio Gonçalves Couto e Rogério} Bastos Arantes

\section{Palavras-chave:}

Constitucionalismo; Democracia; Políticas públicas; Processo governamental; Mudança constitucional.

A Constituição brasileira de 1988 apresenta uma elevada taxa de emendamento constitucional, com 58 emendas constitucionais em dezoito anos (3,22 emendas por ano), na maior parte das vezes patrocinadas pelo Poder Executivo, visando à implementação de políticas públicas. Como o programa governamental pós-1988 permaneceu como uma agenda constituinte, com implicações importantes para as relações do Executivo com o Congresso e o Judiciário, a compreensão da dinâmica política brasileira atual passa necessariamente pelo entendimento de nosso perfil constitucional. Tendo isso em vista, este artigo analisa o perfil da Carta de 1988 com base em seu conteúdo, distinguindo em que medida o texto constitucional - além de normas constitucionais propriamente ditas - contempla políticas públicas, que aumentam a probabilidade de que ele se torne objeto de iniciativas de mudança. Essa análise é feita por meio de uma Metodologia de Análise Constitucional (MAC), desenvolvida pelos autores, que permite uma interpretação do significado dos dispositivos constitucionais e sua mensuração.

\section{CONSTITUTION, GOVERNMENT, AND DEMOCRACY IN BRAZIL}

Cláudio Gonçalves Couto and Rogério Bastos Arantes

Keywords: Constitutionalism; Democracy; Public policies; Governmental process; Constitutional change.

The Brazilian constitution of 1988 has a high rate of constitutional amendmenting, with 58 amendments in eighteen years (3.22 amendments per year), most of the times sponsored by the Executive Power, aiming at implementing public policies. Due to the fact that the post-1988 governmental program has abided a constituent agenda with important implications towards the relations between the Executive and both the Congress and the Judiciary, the comprehension of the current Brazilian political dynamics passes necessarily through the understanding of our constitutional profile. Considered that, this article analyses the profile of the 1988 constitution based on its contents discerning to what extent the constitutional text - as well as constitutional norms - contemplate public policies, causing it to be more prone to change initiatives. Such analysis has been done by means of a Constitutional Analysis Methodology (Metodologia de Análise Constitucional - MAC) developed by the authors, which allows for the interpretation of the constitutional devices meaning as well as its measurement.

\section{CONSTITUTION, GOUVERNEMENT ET DÉMOCRATIE AU BRÉSIL}

\author{
Cláudio Gonçalves Couto et \\ Rogério Bastos Arantes
}

Mots-clés : Constitutionnalisme; Démocratie; politiques Publiques; Processus Gouvernemental; Modification Constitutionnelle.

La Constitution brésilienne de 1988 a été modifiée à plusieurs reprises. Elle compte 58 amendements en 18 ans, ce qui correspond à 3,22 amendements par an. La plupart de ces amendements sont issus du Pouvoir Exécutif dans le but de mettre en place des politiques publiques. Étant donné que le programme gouvernemental postérieur à 1988 est demeuré un agenda constitutionnel, avec d'importantes implications en ce qui concerne les relations entre l'Éxécutif par rapport au Congrès et au Judiciaire, la compréhension de la dynamique politique brésilienne actuelle passe nécessairement par la compréhension de notre profil constitutionnel. Dans ce contexte, cet article analyse la Constitution de 1988 par rapport à son contenu. Il distingue dans quelle mesure le texte constitutionnel - mis à part les règles constitutionnelles proprement dites - contemple les politiques publiques, qui augmentent la probabilité que la Constitution ne fasse l'objet d'initiatives d'amendements. Cette analyse est proposée par l'emploi d'une méthodologie d'Analyse Constitutionnelle (MAC) développée par les auteurs, de façon à permettre une interprétation des dispositifs constitutionnels et les évaluer. 